\title{
Perancangan Aplikasi Penyajian Informasi Denah Pusat Perbelanjaan XYZ Mall Menggunakan Flash
}

\author{
Hendra Mayatopani ${ }^{1}$, Laser Narindro² ${ }^{\text {, Riskita Paramitha }}{ }^{3}$ \\ Universitas Muhammadiyah Tangerang / Program Studi Informatika ${ }^{\mathbf{1}}$, \\ Universitas Bina Nusantara / Program Studi Manajemen Sistem Informasi², \\ Universitas Trisakti / Program Studi Informatika ${ }^{3}$ \\ JI. Perintis Kemerdekaan 1/33 Cikokol Kota Tangerang TLP. 55793251, 55772949, 55793802, 55736926 \\ e-mail: dra_maya_topani@yahoo.com¹, laser_narindro87@yahoo.com², \\ riskita.paramitha@yahoo.com ${ }^{3}$
}

\begin{abstract}
ABSTRAK
Pembuatan aplikasi berbasis multimedia berupa sistem informasi tata letak ruang visual dengan menggunakan aplikasi adobe flash, merupakan sebuah perangkat lunak yang dapat mempresentasikan citra lingkungan sekitar mendekati situasi sesungguhnya. Lokasi yang akan menjadi objek pada pembuatan tugas akhir ini adalah pusat perbelanjaan yang terdapat gedung $X Y Z$ Mall, Jakarta. Pengembangan sistem informasi tata letak ruang visual ini merupakan pengembangan sistem tata letak ruang berbasis multimedia pada pusat perbelanjaan yang terdapat pada XYZ Mall menjadi visualisasi tentang tata letak ruang berbasis multimedia agar mempermudah para pengunjung dalam pencarian lokasi perbelanjaan yang ingin dituju. Dengan penerapan teknologi flash dalam pencitraan dua dimensi ini diharapkan dapat menghasilkan pencitraan yang detail dan interaktif pada pusat perbelanjaan gedung $X Y Z$ Mall dimana pencitraan tata letak ruang secara visual tersebut diharapkan dapat memberikan user experience yang bersifat nyata sehingga tingkat pemahaman yang user friendly terhadap hasil pencitraan akan lebih tinggi.
\end{abstract}

Kata kunci: Aplikasi multimedia, tata letak ruang, informasi denah, system informasi.

\begin{abstract}
Making multimedia based applications such as an information systems of layout space by visual using Adobe Flash, application is a software that can present the image of the surrounding to the real situation. Locations that will be the object of the making of this thesis is a shopping center building of $X Y Z$ Mall, Jakarta. Development of information systems of layout space by visual is a development system based spatial layout of multimedia in the shopping center where located at XYZ Mall into a visualization of layout space with multimedia based to facilitate the visitors for search of shopping locations. With implementation with flash application by two dimensional is expected to produce a detailed and interactive visual on $X Y Z$ Mall shopping center building where the imaging space visually layout is expected to provide a user experience that is real that the level of understanding that is user friendly to the imaging results will be high.
\end{abstract}

Keywords: Multimedia application, layout space, layout information, information system

\section{PENDAHULUAN}

Pemetaan dan pelacakan tata letak ruangan pada sebuah gedung telah lama dilihat sebagai sektor potensial bagi pemilik gedung perbelanjaan. Para analis dan pendukung teknologi berpendapat bahwa aplikasi tata letak ruang dapat membantu mengarahkan Pengunjung untuk mencapai toko (merchant), resto atau tempat yang diinginkan dalam suatu gedung perbelanjaan. Dimana Pengunjung yang datang pada gedung perbelanjaan tersebut hanya cukup datang ke mesin pencari toko tersebut yang telah disediakan oleh pemilik gedung perbelanjaan pada titik tertentu yang telah ditentukan.

Pemetaan 2D dapat dilakukan dengan menggunakan teknologi tata letak ruang. Aplikasi tata letak ruang 2 merupakan sistem perangkat lunak yang 
dirancang untuk menciptakan dan mengembangkan visualisasi pada rute lokasi suatu objek.

Dengan adanya aplikasi tata letak ruang ini, maka diharapkan pengunjung mendapatkan informasi tentang rute lokasi ruang tersebut dalam bentuk visual yang mudah dikenali.

\subsection{Rumusan Masalah}

Bagaimana menganalisa dan merancang sebuah aplikasi tata letak ruang yang detail, informatif dan interaktif sehingga dapat memberikan user experience yang bresifat nyata bagi para Pengunjung dan tingkat pemahaman yang user friendly serta dapat memberikan informasi yang lengkap dan mendetail terhadap objek yang dituju.

Menurut Octafian (2011, p20) sistem informasi dapat didefenisikan sebagai berikut :

1) Suatu sistem yang dibuat oleh manusia yang terdiri dari komponen-komponen dalam organisasi untuk mencapai suatu tujuan yaitu menyajikan informasi.

2) Sekumpulan prosedur organisasi yang pada saat dilaksanakan akan memberikan informasi bagi pengambil keputusan dan/ atau untuk mengendalikan organisasi.

3) Suatu sistem didalam suatu organisasi yang mempertemukan kebutuhan pengolahan transaksi, mendukung operasi, bersifat manajerial, dan kegiatan strategi dari suatu organisasi dan menyediakan pihak luar tertentu dengan laporanlaporan yang diperlukan.

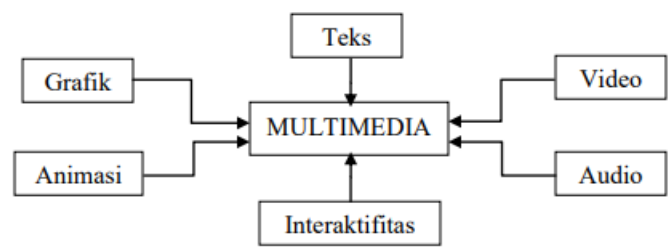

Gambar 1. Definisi multimedia (S.C Lowa Sada, 2011)
Beberapa pengertian multimedia menurut Charolus S.C Lowa Sada (2011, p4) yang dikutip dari Sofyan dan Purwanto sebagai berikut :

1. Multimedia berarti suatu sistem yang terdiri dari perangkat keras, perangkat lunak dan alat-alat lain seperti televisi, monitor video dan sistem piringan optik atau system stereo yang di maksud untuk menghasilkan sajian audio visual penuh.

2. Multimedia secara umum merupakan kombinasi 3 elemen yaitu suara, gambar dan teks.

3. Multimedia juga merupakan kombinasi dari paling sedikit 2 media input dan output dari data. Media ini dapat berupa audio (suara, musik), animasi, video, teks, grafik, dan gambar.

4. Multimedia merupakan alat yang dapat menciptakan presentasi yang dinamis dan interaktif yang mengkombinasikan teks, grafik, animasi, audio, dan gambar video.

5. Multimedia adalah pemanfaatan komputer untuk membuat dan menggabungkan teks, grafik, audio, gambar bergerak (video dan animasi) dengan menggabungkan link dan tool yang memungkinkan pemakai melakukan navigasi, berinteraksi, berkreasi dan berkomunikasi.

Menurut S.C Lowa Sada (2011) Prinsip dasar dalam pembuatan animasi merupakan bagian penting dalam menghidupkan karakter animasi menjadi tampak lebih hidup dan tidak terlihat kaku, namun justru membuat karakter animasi tersebut seolah-olah memiliki jiwa. Berikut beberapa prinsip pada animasi, yaitu :

1. Squash and Stretch

2. Anticipation

3. Staging

4. Straight Ahead Action and Pose to Pose

5. Follow Through and Overlaping Action 
6. Slow In Slow Out

7. Arcs

8. Secondary Action

9. $\quad$ Timing

10. Exaggeration

11. Solid Drawing

12. Appeal

Flash merupakan software yang memiliki kemampuan menggambar sekaligus menganimasikannya, serta mudah dipelajari (Amarullah Akbar et al, 2008). Flash tidak hanya digunakan dalam pembuatan animasi, tetapi pada zaman sekarang ini flash juga banyak digunakan untuk keperluan lainnya seperti dalam pembuatan game, presentasi, membangun web, animasi pembelajaran, bahkan juga dalam pembuatan film. Animasi yang dihasilkan flash adalah animasi berupa file movie. Movie yang dihasilkan dapat berupa grafik atau teks. Grafik yang dimaksud disini adalah grafik yang berbasis vektor, sehingga saat diakses melalui internet, animasi akan ditampilkan lebih cepat dan terlihat halus. Selain itu flash juga memiliki kemampuan untuk mengimpor file suara, video maupun file gambar dari aplikasi lain. (Amarullah et al, 2008).

Bahasa pemodelan merupakan bagian terpenting dari metode. Ini merupakan bagian kunci tertentu untuk komunikasi. Jika anda ingin berdiskusi tentang desain dengan seseorang, maka hanya membutuhkan bahasa pemodelan bukan proses yang digunakan untuk mendapatkan desain. (Ramadian, Fetty \& Jayantha. 2009) UML merupakan bahasa standar untuk penulisan blueprint software yang digunakan untuk visualisasi, spesifikasi, pembentukan dan pendokumentasian alatalat dari sistem perangkat lunak. (Ramadian, Fetty \& Jayantha. 2009)
Menurut Joan Nugroho (2012, p1)

UML merupakan suatu metode untuk menganalisa proses bisnis dan kemudian memodelkannya dalam notasi tertentu. notasi-notasi tersebut mempunyai aturan khusus yang mencerminkan suatu pengertian tertentu.

\section{METODE PENELITIAN}

Langkah dalam melakukan metode yang dilakukan untuk menujang analisa dilakukan dengan tahapan sebagai berikut :

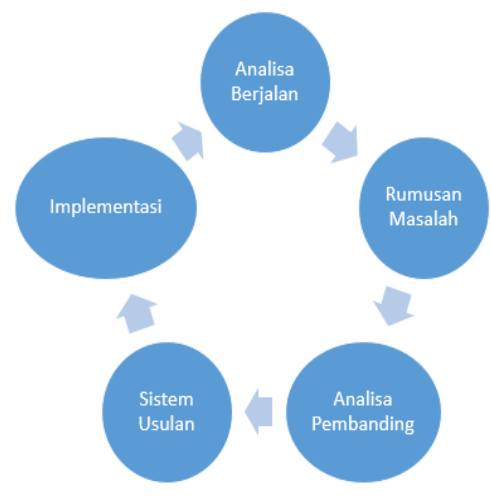

Gambar 2. Alur Proses Analisa

Pada sistem yang sedang berjalan, informasi tentang lokasi toko yang akan dikunjungi oleh Pengunjung masih menggunakan komunikasi verbal dimana Pengunjung tersebut akan mengunjungi pusat informasi yang terdapat di dalam gedung perbelanjaan dan Petugas pusat informasi tersebut akan memberikan informasi pengarahan lokasi secara komunikasi verbal kepada Pengunjung, sehingga Pengunjung belum memiliki gambaran yang jelas terhadap arah yang pasti untuk toko yang akan dikunjungi.

Melihat sistem yang sedang berjalan pada saat ini, diperlukan suatu sistem informasi yang dapat meningkatkan kinerja manajemen terhadap pelayanan informasi kepada setiap Pengunjung XYZ Mall, sehingga informasi yang diberikan lebih detail dan interaktif. Gambar 2.1 berikut adalah gambar activity diagram yang sedang berjalan pada sistem informasi tata letak ruang pada XYZ Mall. 


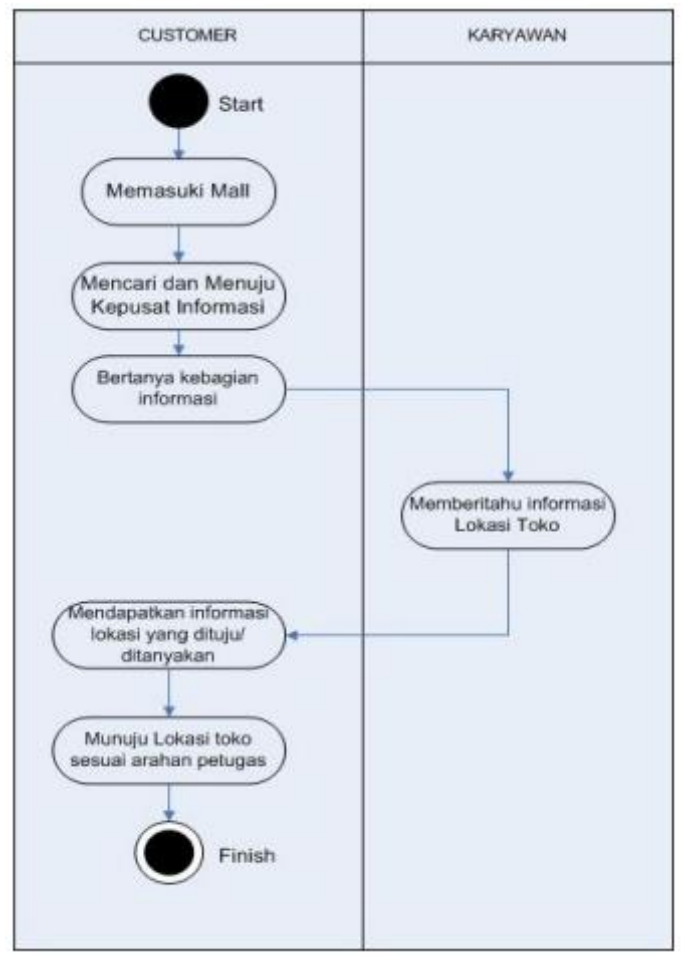

Gambar 2. Activity diagram sistem yang sedang berjalan

\subsection{Analisa Pembanding}

Adapun analisa pembanding aplikasi sejenis yang telah diterapkan pada pusat perbelanjaan lainnya. Dimana aplikasi tersebut telah diimplementasikan pada Mall. Adapun spesifikasi yang terdapat pada aplikasi tata letak ruang pada Mall yaitu :

1. Terdapat informasi penunjuk arah dari titik satu ke titik berikutnya

2. Pencarian lokasi toko dibedakan berdasarkan jenis pelayanan toko bukan berdasarkan alfabet nama dari setiap toko.

3. Disertai menu informasi tentang promo kartu kredit, fasilitas umum dan kontak manajemen gedung. Adapun beberapa fitur yang terdapat pada sistem informasi tata letak ruang yang terdapat pada Mall, yaitu :

1. Shopping Directory

2. Promo Credit Card
3. Event \& Promo
4. Public Facility
5. Content Management
6. List Counter

Untuk memperjelas gambaran tentang visualisasi aplikasi tata letak ruang pada Mall $X Y Z$, dapat melihat gambar 3 .

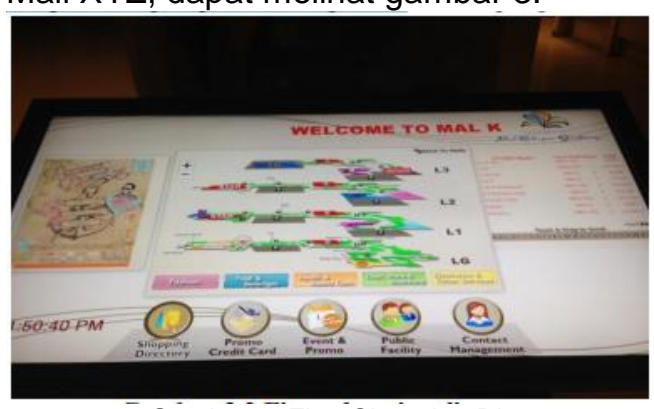

Gambar 3. Fitur Shopping Directory

Pengunjung Mall akan mendatangi mesin tata letak ruang yang terdapat dalam gedung. Lalu Pengunjung akan melihat sistem informasi tata letak ruang tersebut yang disertai dengan gambar visual tentang lokasi pertokoan yang terdapat pada Mall serta titik lokasi mesin tersebut berada sehingga Pengunjung juga dapat mengetahui lokasi Pengunjung berada. Selain itu Pengunjung juga akan mendapatkan informasi tentang namanama pertokoan berdasarkan kategori pertokoan yang terdapat pada Mall.

\subsection{Perancangan Sistem yang Diusulkan}

Dari analisa dan pengamatan sistem yang sedang berjalan dengan kekurangankekurangan yang ada, maka diperlukan pembuatan suatu sistem yang paling tepat untuk mengatasi permasalahan di atas adalah dengan menggunakan sistem informasi tata letak ruang. Adapun keuntungan yang didapatkan dari pemakaian aplikasi tata letak ruang adalah sebagai berikut :

1 Pengunjung dapat melihat persebaran lokasi toko dalam satu area tertentu.

2 Pengunjung dapat melihat informasi tentang toko yang terdapat dalam gedung Mall.

3 Pengunjung dapat mengetahui rute perjalanan dari titik peta yang telah 
ditentukan menuju toko yang ingin dikunjungi.

Untuk dapat menghasilkan aplikasi tata letak ruang yang maksimal maka diperlukan suatu perancangan sistem yang menggunakan metode UML (unified modeling language) berupa use case diagram dan activity diagram.

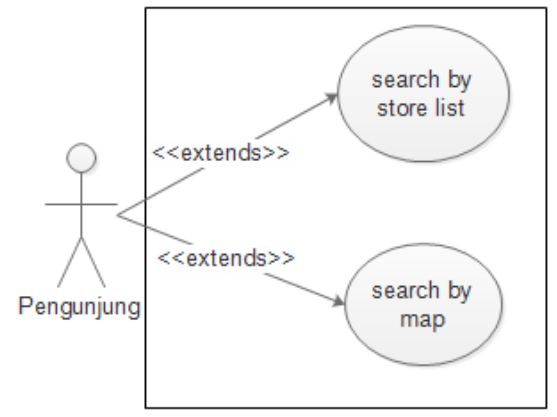

Gambar 4. Use case diagram tata letak ruang diusulkan

Penjelasan sebagai berikut :

1. Deskripsi use case menjalankan aplikasi. Deskripsi singkat : use case ini menjelaskan proses pengunjung untuk memberikan informasi lokasi yang dituju dalam menjalankan aplikasi.

2. Deskripsi use case memilih kategori pada halaman utama. Deskripsi singkat : use case ini mennjelaskan proses pengunjung untuk masuk ke dalam memilih kategori pada halaman utama.

a. Pengunjung memilih kategori pada halaman utama.

b. Sistem akan menampilakan kategori pada halaman utama yang terdapat 2 (dua) menu yaitu "search by store list" dan "search by map".

3. Deskripsi use case memilih kategori pada halaman "search by store list" tentang pencarian nama toko yang terdapat didalam mall.

Deskripsi singkat: use case ini mendeskripsikan proses pengunjung pada saat memilih kategori pada halaman "search by store list" tentang pencarian nama toko yang terdapat di dalam mall.

a. Nama toko tujuan
1) Pengunjung memilih halaman tentang pencarian nama toko yang terdapat didalam mall.

2) Sistem akan menampilkan halaman tentang hasil pencarian nama toko berdasarkan "search by store list" yang terdapat didalam mall.

b. Informasi toko

1) Pengunjung mendapatkan informasi tentang nama toko yang terdapat didalam mall.

2) Sistem akan menampilkan halaman tentang informasi nama toko berdasarkan informasi toko yang terdapat didalam mall.

c. Gate Map Peta

1) Pengunjung memilih halaman tentang gate map peta toko yang terdapat didalam mall.

2) Sistem akan menampilkan halaman tentang gate map peta toko berdasarkan gate map yang terdapat didalam mall.

d. Informasi rute dari posisi lantai

1) Pengunjung memilih halaman tentang informasi rute toko dari posisi lantai yang terdapat didalam mall.

2) Sistem akan menampilkan informasi rute toko dari posisi lantai berdasarkan informasi rute yang terdapat didalam mall.

4. Deskripsi use case memilih kategori pada halaman "search by map" tentang pencarian peta toko yang terdapat di dalam mall.

Deskripsi singkat : use case ini mendeskripsikan perihal proses pengunjung pada saat memilih kategori pada halaman "search by map" tentang pencarian peta toko yang terdapat di dalam mall. 
a. Memilih peta sesuai lantai

1) Pengunjung memilih halaman tentang pencarian peta/map toko yang terdapat didalam mall.

2) Sistem akan menampilkan halaman tentang hasil pencarian peta/map toko berdasarkan lantai yang terdapat didalam mall.

b. Denah toko

1) Pengunjung mendapatkan informasi tentang denah toko yang terdapat di dalam mall.

2) Sistem akan menampilkan halaman tentang informasi denah toko berdasarkan tata letak ruang yang terdapat di dalam mall.

c. Informasi jalur rute map toko

1) Pengunjung mendapatkan informasi tentang informasi jalur map toko yang terdapat di dalam mall.

2) Sistem akan menampilkan halaman tentang informasi informasi jalur map toko berdasarkan tata letak ruang pada posisi lantai yang terdapat di dalam mall.

Activity diagram merupakan representasi grafis dari alur kerja tahapan aktivitas yang dilakukan pada aplikasi multimedia tata letak ruang ini. Proses alur data aplikasi tata letak ruang tersebut dapat dilihat pada gambar 5 .

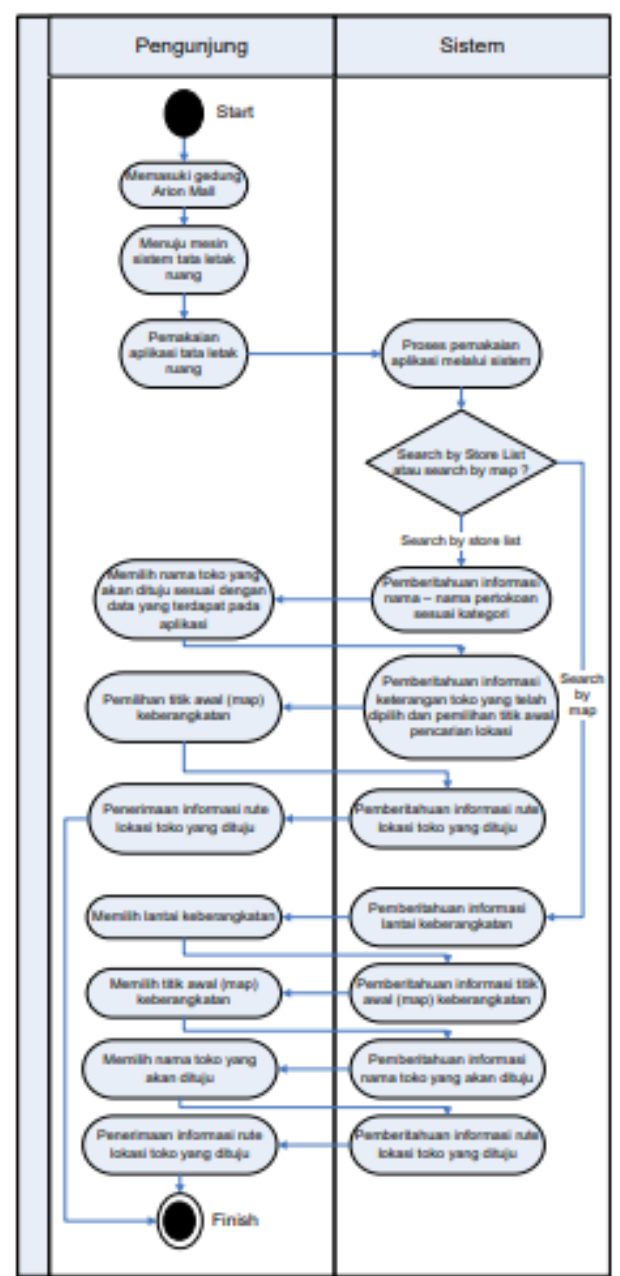

Gambar 5. Activity diagram tata letak ruang diusulkan

Berikut adalah penjelasan Gambar 5 yaitu :

1. Pengunjung memasuki area gedung perbelanjaan Mall

2. Pengunjung akan menuju ke mesin informasi tata letak ruang.

3. Pengunjung akan mencari informasi tentang lokasi toko yang akan dikunjungi melalui mesin tata letak ruang yang telah disediakan oleh Manajemen Pengelola Gedung Mall.

4. Pengunjung akan memilih menu pencarian toko berdasarkan nama toko atau berdasarkan lantai.

5. Jika berdasarkan nama toko maka Pengunjung akan memilih nama toko yang ingin dikunjungi terlebih dahulu sesuai kategori toko tersebut. 
6. Setelah memilih nama toko tersebut, maka Pengunjung akan memilih lokasi lantai tempat Pengunjung berada.

7. Lalu Pengunjung akan ditampilkan rute menuju toko yang telah dipilih sebelumnya berdasarkan lokasi tempat Pengunjung berada.

8. Jika Pengunjung memilih berdasarkan lantai maka Pengunjung harus memilih lokasi lantai tempat Pengunjung berada.

9. Lalu Pengunjung harus memilih map berapa yang diinginkan.

10. Lalu Pengunjung harus memilih toko yang ingin dituju dan aplikasi tata letak ruang tersebut akan memberikan informasi rute arah menuju lokasi toko dari map yang telah dipilih sebelumnya.

Story board aplikasi tata letak ruang yang diusulkan.

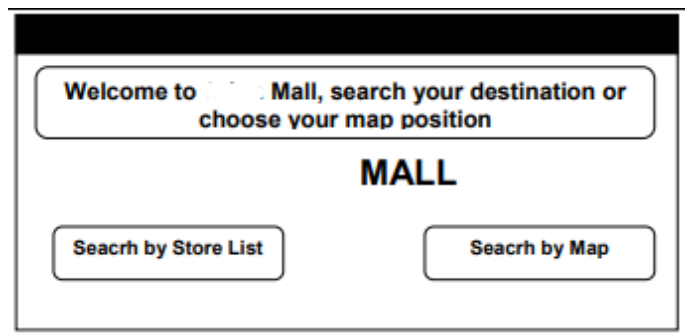

Frame 1 Pada awal masuk ke aplikasi, ditampilkan halaman yang merupakan menu utama aplikasi Mall.

1. Tulisan berjalan "Welcome to Mall, search your destination or choose your map position" dan Mall

2. Setelah itu, Pengunjung akan memilih button "Search by Store List" atau "Search by Map".

Setelah frame 1 ditampilkan maka lanjut ke frame selanjutnya.

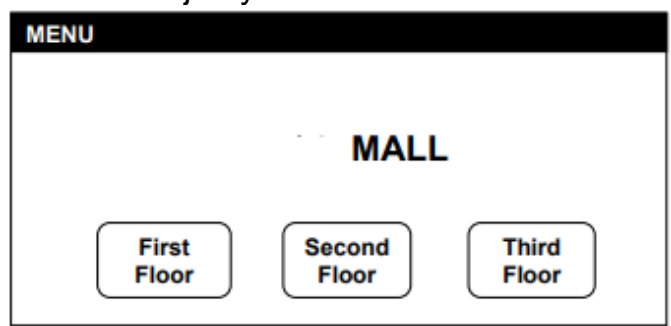

Frame 2 Frame ini akan muncul apabila Pengunjung memilih button Search by Map, maka tampilannya akan seperti halaman berikut :

1. Tombol "Menu" untuk untuk menampilkan "Map Search", "View Store List" dan "Main Menu".

2. Button "First Floor" yaitu menu yang akan menampilkan denah lokasi Mall lantai 1.

3. Button "Second Floor" yaitu menu yang akan menampilkan denah lokasi Mall lantai 2.

4. Button "Third Floor" yaitu menu yang akan menampilkan denah lokasi Mall lantai 3.

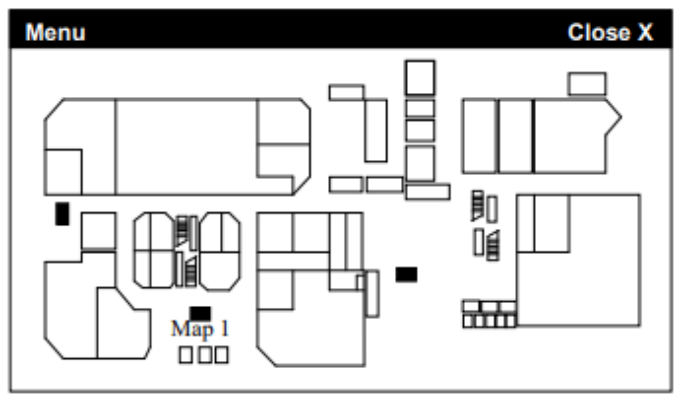

Frame 3 Frame ini apabila Pengunjung menekan button "First Floor", maka tampilannya akan seperti halaman berikut :

1. Tombol "Menu" untuk untuk menampilkan "Map Search", "View Store List" dan "Main Menu".

2. Tombol close untuk kembali ke menu sebelumnya.

3. Gambar kotak-kotak yang merupakan denah dari toko yang berada di lantai 1 Mall.

4. 1 buah kotak kecil yang merupakan map, tempat Pengunjung berawal menuju lokasi berikutnya.

Setelah pengunjung memilih map, maka akan terlihat alamat blok toko di dalam denah. 


\section{HASIL DAN ANALISIS}

Untuk menjalankan aplikasi tata letak ruang tesebut, adapun langkahlangkah yang perlu dilakukan sebagai berikut :

1. Klik data aplikasi tata letak ruang tersebut

2. Setelah aplikasi tersebut terbuka, akan terlihat tampilan awal aplikasi tersebut seperti pada Gambar 6 dibawah ini.
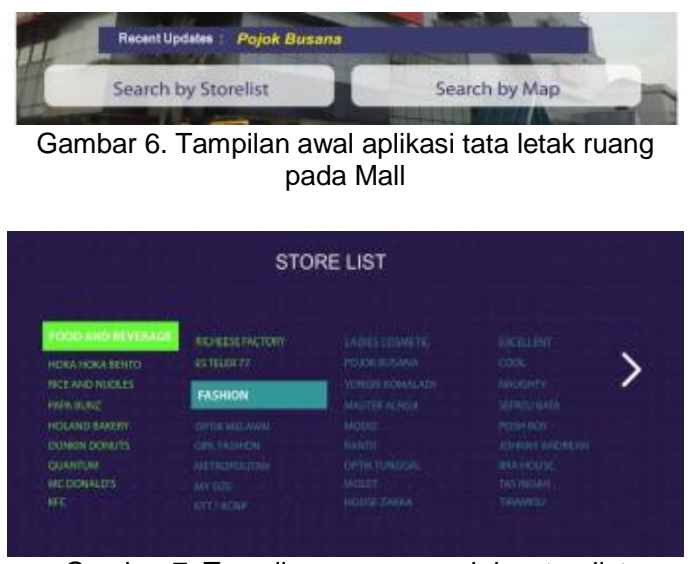

Gambar 7. Tampilan menu search by storelist

Gambar diatas menampilkan pengunjung akan memilih nama toko yang akan dikunjungi. Setelah itu akan tampil form informasi toko seperti Gambar 8

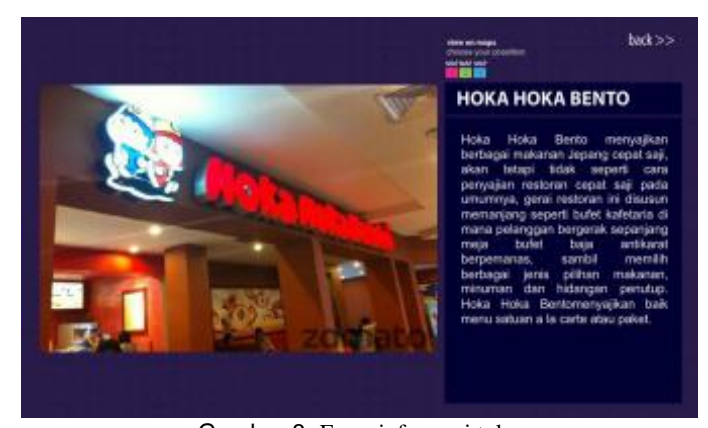

Gambar 8. Form informasi toko

selain menampilkan informasi tentang toko yang telah dipilih juga memberikan pilihan kepada Pengunjung untuk memilih lantai berapa Pengunjung memulai rute menuju toko tersebut.

Setelah itu Pengunjung akan ditampilkan arah (rute) menuju lokasi toko tersebut berdasarkan lantai yang telah dipilih sebelumnya sehingga Pengunjung dapat mengerti informasi rute yang disajikan pada aplikasi. Tampilan tersebut dapat dilihat pada gambar 9

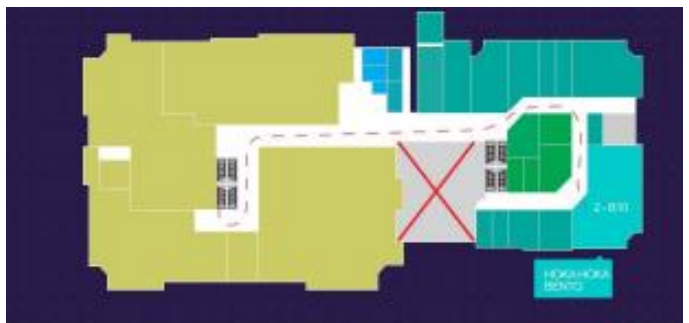

Gambar 9. Denah arah dari titik awal menuju titik yang dituju

Penilaian aplikasi tersebut berdasarkan pertanyaan yang telah dibuat sebelumnya. Jumlah kuesioner yang disebarkan sebanyak 50 buah. Sedangkan untuk demografi responden dapat dilihat pada table 1

Table 1. Profil responden

\begin{tabular}{|l|l|}
\hline Nama Variabel & \multicolumn{1}{|c|}{ Nilai } \\
\hline Usia responden & $\begin{array}{l}\text { 1. } 16-20 \text { tahun }=8 \text { orang } \\
\end{array}$ \\
& 2. $21-30$ tahun $=23$ orang \\
& 3. $31-40$ tahun $=13$ orang \\
\hline Jenis kelamin $41-50$ tahun $=6$ orang \\
\hline Waktu pemakaian & 1. Pria $=29$ orang \\
& 2. Wanita $=21$ orang \\
\hline & Kurang lebih sekitar 5 menit per Pengunjung \\
& untuk memakai aplikasi ini hingga paham \\
\hline
\end{tabular}

Hasil survei berupa kuesioner yang telah disebarkan kepada 50 responden Pengunjung (pemakai aplikasi) setelah menjalankan aplikasi tata letak ruang ini. Pengisian form kuesioner penelitian terhadap kepuasan pemakai aplikasi ini terlampir pada laporan penelitian ini. Adapun indeks penilaian kepuasan Pengguna aplikasi peta digital dapat diasumsikan sebagai berikut : Adapun hasil dari survei kepuasan ini yang terdiri dari 8 pertanyaan yang diajukan kepada 50 Pengunjung Mall selaku pengguna aplikasi tata letak ruang yaitu sebagai berikut :

i. Bagaimana dengan tampilan (interface) dan pewarnaan pada aplikasi ?

\begin{tabular}{|l|c|c|}
\hline \multicolumn{1}{|c|}{ Nama Variabel } & Jumlah & Persentase \\
\hline Sangat Baik & 28 orang & $56 \%$ \\
\hline Baik & 13 orang & $26 \%$ \\
\hline Cukup Baik & 8 orang & $16 \%$ \\
\hline Kurang Baik & 1 orang & $2 \%$ \\
\hline \multicolumn{2}{|c|}{ Jadi, menurut hasil kuesioner rata - rata 82 \%, Pengunjung menilai tampilan } \\
\hline
\end{tabular}

pada aplikasi tata letak ruang ini adalah user friendly. 
ii. Bagaimana tingkat kecepatan dalam pemrosesan informasi ?

\begin{tabular}{|l|c|c|}
\hline \multicolumn{1}{|c|}{ Nama Variabel } & Jumlah & Persentase \\
\hline Sangat Cepat & 35 orang & $70 \%$ \\
\hline Cepat & 7 orang & $14 \%$ \\
\hline Cukup Cepat & 8 orang & $16 \%$ \\
\hline Kurang Cepat & 0 orang & $0 \%$ \\
\hline
\end{tabular}

Jadi, menurut hasil kuesioner rata - rata $84 \%$, Pengunjung menilai tingkat kecepatan dalam permroresan informasi yang terdapat pada aplikasi ini sudah cukup untuk mendukung dalam pengoperasian aplikasi ini.

iii. Bagaimana tingkat akurasi dan ketepatan pemberian informasi ?

\begin{tabular}{l|c|c|}
\hline \multicolumn{1}{|c|}{ Nama Variabel } & Jumlah & Persentase \\
\hline Sangat Cepat & 35 orang & $70 \%$ \\
\hline Cepat & 7 orang & $14 \%$ \\
\hline Cukup Cepat & 8 orang & $16 \%$ \\
\hline Kurang Cepat & 0 orang & $0 \%$ \\
\hline \multicolumn{2}{|c|}{ Jadi, menurut hasil kuesioner rata - rata $84 \%$, Pengunjung menilai tingkat } \\
kecepatan dalam permmoresan informasi yang terdapat pada aplikasi ini sudah \\
cukup untuk mendukung dalam pengoperasian aplikasi ini.
\end{tabular}

iv. Bagaimana tingkat kesesuaian visualisasi dengan keadaan nyata?

\begin{tabular}{|l|c|c|}
\hline \multicolumn{1}{|c|}{ Nama Variabel } & Jumlah & Persentase \\
\hline Sangat Baik & 28 orang & $56 \%$ \\
\hline Baik & 15 orang & $30 \%$ \\
\hline Cukup Baik & 7 orang & $14 \%$ \\
\hline Kurang Baik & 0 orang & $0 \%$ \\
\hline \multicolumn{2}{|c|}{ Jadi, menurut hasil kuesioner rata - rata $86 \%$, Pengunjung dapat langsung }
\end{tabular}
memahami pemakaian aplikasi tata letak ruang ini.

v. Apakah Pengunjung Arion Mall menyukai aplikasi tata letak ruang ini ?

\begin{tabular}{|l|c|c|}
\hline \multicolumn{1}{|c|}{ Nama Variabel } & Jumlah & Persentase \\
\hline Sangat Suka & 38 orang & $76 \%$ \\
\hline Suka & 11 orang & $22 \%$ \\
\hline Cukup Suka & 1 orang & $2 \%$ \\
\hline Kurang Suka & 0 orang & $0 \%$ \\
\hline
\end{tabular}

Jadi, menurut hasil kuesioner rata - rata $98 \%$, Pengunjung menyukai aplikasi atat letak ruang ini.

vi. Bagaimana tingkat kepuasan Pengunjung terhadap pemakaian aplikasi peta tata letak ruang ini ?

\begin{tabular}{|l|c|c|}
\hline \multicolumn{1}{|c|}{ Nama Variabel } & Jumlah & Persentase \\
\hline Sangat Puas & 42 orang & $84 \%$ \\
\hline Puas & 4 orang & $8 \%$ \\
\hline Cukup Puas & 4 orang & $8 \%$ \\
\hline Kurang Puas & 0 orang & $0 \%$ \\
\hline
\end{tabular}

Jadi, menurut hasil kuesioner rata - rata $92 \%$, Pengunjung merasakan kepuasannya terhadap pemakaian aplikasi ini. vii. Apakah aplikasi tata letak ruang sudah sesuai dengan kebutuhan Pengunjung ?

\begin{tabular}{|l|c|c|}
\hline \multicolumn{1}{|c|}{ Nama Variabel } & Jumlah & Persentase \\
\hline Sangat Sesuai & 41 orang & $82 \%$ \\
\hline Sesuai & 9 orang & $18 \%$ \\
\hline Cukup Sesuai & 0 orang & $0 \%$ \\
\hline Kurang Sesuai & 0 orang & $0 \%$ \\
\hline \multicolumn{2}{|c|}{ Jadi, menurut hasil kuesioner rata - rata $100 \%$, Pengunjung menilai aplikasi } \\
\hline
\end{tabular}

ini sudah sesuai dengan kebutuhan Pengunjung.

viii. Apakah aplikasi tata letak ruang ini bermanfaat bagi para Pengunjung ?

\begin{tabular}{|c|c|c|}
\hline Nama Variabel & Jumlah & Persentase \\
\hline Sangat Bermanfaat & 31 orang & $70 \%$ \\
\hline Bermanfaat & 7 orang & $14 \%$ \\
\hline Cukup Bermanfaat & 8 orang & $16 \%$ \\
\hline Kurang Bermanfaat & 0 orang & $0 \%$ \\
\hline
\end{tabular}

\section{KESIMPULAN}

Kesimpulan yang dapat diperoleh dalam pengerjaan aplikasi tata letak ruang pada XYZ Mall berbasis multimedia ini adalah sebagai berikut :

1. Analisa dan perancangan aplikasi tata letak ruang pada $X Y Z$ mall ini menggunakan aplikasi Adobe Flash. Aplikasi tata letak ruang ini berisikan tentang informasi penunjuk arah menuju toko yang ingin dituju dan informasi seputar outlet atau toko secara detail dan interaktif sehingga dapat menghasilkan user experience yang bersifat nyata dan user friendly yang berbasis multimedia.

2. Menurut perhitungan kuesioner yang telah dilakukan sebelumnya sebesar 84 $\%$ Pengujung yang telah menjalani aplikasi tata letak ruang ini menilai bahwa aplikasi tata letak ruang dapat bermanfaat bagi para Pengunjung jika aplikasi ini dapat diimplementasikan.

3. Sedangkan menurut perhitungan kuesioner, lebih dari $85 \%$ Pengunjung XYZ Mall yang telah menjalani aplikasi tata letak ruang ini menilai bahwa tampilan (warna, kecepatan, akurasi 
dan kecepatan, visualisasi, dan tata letak) pada aplikasi tata letak ruang ini sudah user friendly.

\section{REFERENSI}

[1] Andi. 2004. "Aplikasi Program Php Dan Mysql Untuk Membuat Website Interaktif". Yogyakarta: Andi Offset.

[2] Anshari, Muh. Nadzirim. 2013. "Pengembangan Authoring Tool Animasi Untuk Pembuatan Media Pembelajaran

Interaktif".Http://Pasca.Unhas.Ac.Id/Jur nal/Files/241a9417c8ff51bf81

45f7eda1272660.Pdf. 19 Januari 2014

[3] Astuti, Karina Dewi. 2012. "Perancangan Aplikasi Di Ukm". Http://Repository.Widyatama.Ac.ld/Xml ui/Bitstream/Handle/123456789/22 04/1107019.Pdf?Sequence $=1 . \quad 19$ Januari 2014

[4] A. Nugroho, Mawan. 2013. "12 Prinsip Animasi".

Http://Www.Mawan.Or.Id/Files/Pdf/12\% 20prinsip\%20animasi.Pdf. 15 Mei 2014
[5] Binanto, Iwan. 2010. "Multimedia Digital : Dasar Teori Dan Pengembangannya". Jakarta : Andi Publisher

[6] .Pamungkas, Octavian Bayu. 2011. "Pembuatan Animasi 2 D Dengan Teknik Rotoscoping". Http://Repository.Amikom.Ac.Id/Files/P ublikasi_03110414.Pdf. 19 Januari 2014

[7] S.C Lowa Sada, Charolus. 2011. "Perancangan Film Animasi 2d "Paijo Dan Broken"'. Http://Repository.Amikom.Ac.Id/Files/P ublikasi_07.12.2712.Pdf. 19 Januari 2014

[8] Syahbana. Volume 1 Nnomor 2. 2011. "Sistem Informasi Akademik Berbasis Multimedia Pada Lembaga Pendidikan Palembang Technology". Http://News.Palcomtech.Com/Wpconte nt/Uploads/2012/01/SyachbanaTe01022011.Pdf. 19 Januari 2014 